Article

\title{
The Economic Sustainability of Snow Tourism: The Case of Ski Resorts in Austria, France, and Italy
}

\author{
Jordi Moreno-Gené (D), Laura Sánchez-Pulido, Eduard Cristobal-Fransi ${ }^{(D)}$ and Natalia Daries * (D) \\ Department of Business Management, University of Lleida, C/Jaume II, 73, 25001 Lleida, Spain; \\ jmoreno@aegern.udl.cat (J.M.-G.); lsanchez@aegern.udl.cat (L.S.-P.); ecristobal@aegern.udl.cat (E.C.-F.) \\ * Correspondence: ndaries@aegern.udl.cat; Tel.: +34-97-370-3298
}

Received: 27 June 2018; Accepted: 22 August 2018; Published: 24 August 2018

\begin{abstract}
The purpose of this article is to analyse whether ski resorts in Europe are economically viable. Data originates from the financial statements of the 61 largest ski lift operators in Austria, France, and Italy. Descriptive statistics reveal that these operators are characterized by positive and relatively high returns, and by having little debt in general terms. The results show that the most economically profitable ski operators are also the largest. The elevation of the ski area is not relevant. Ski lift operators in Austria have a higher profitability than those in France and Italy. Overall, larger ski resorts are better prepared for the future investment needed to adapt to the new conditions in the industry, such as climate variability.
\end{abstract}

Keywords: tourism; snow; economic sustainability; skiing; profitability

\section{Introduction}

Winter tourism is an important industry in the European Alps. At present, the sector is in a stagnation phase and, in addition, faces great challenges in the future as well. These include, above all, climate change, but also the change in holiday preferences and increasing interest in city breaks. According to the report compiled by Vanat [1], around 100 countries can be found around the world that offer ski facilities and areas as tourist and sports destinations. In said report, the author identifies around 2000 ski resorts, which attracted over 400 million skiers in 2017-2018 [1]. The authors also finds that mature markets have seen their growth slow, while other emerging markets show significant progress [2].

The study presented here was applied to ski lift operators in Austria, France, and Italy, and analyses the economic sustainability of the resorts in each of these countries. According to data from the Vanat study [1], together with Japan and the United States, these three countries represent an example of the world's biggest ski destinations and have a large number of facilities.

At Austrian resorts, $66 \%$ of skiers come from outside the country's borders [1]. Austria has a strong ski culture and is the only country in which schools regularly continue to have ski weeks [3]. It is also the European country with the largest supply of hotel accommodation. The country's 254 resorts receive an average of 51.7 million skiers per year. For its part, France offers a wide variety of ski slopes. The country's total ski area exceeds $1100 \mathrm{~km}^{2}$, with $325 \mathrm{ski}$ areas attracting over 54 million skiers in the 2016-2017 season. France is, therefore, a mature and established winter sport destination [4]. And finally, the Italian ski industry is similar to the Austrian model and to the tourism centres of western France, in terms of the size of the ski resorts, weather conditions, and skier profile [5]. Italy has 349 skiable areas, which receive 27 million users annually [1].

In these countries, the ski tourism industry represents an important economic sector, and also contributes to related economic activities such as transportation, hotels and restaurants, retail trade, and the rental and sale of sports equipment, etc. [6]. 
Some studies $[7,8]$ show that the population and number of workers in the tertiary sector increase in territories with ski resorts, while the number of people employed in the primary sector decreases. An increase in the number of skiers also leads to an increase in the flow of tourists. This fact shows that the industry is of decisive economic importance for mountain areas $[9,10]$.

The demand for winter tourism depends on several factors: national and international income, prices, transportation, costs, the timing of Easter holidays, and climate change [11]. Climate change has been found to be a key factor, especially for some low-altitude ski resorts. In these resorts, variations in demand are much more pronounced, since they are very dependent on the climate and therefore on the depth of snow on the slopes [11]. Companies prefer to invest in high-altitude ski resorts, aiming to create large ski areas [12-14] that attract foreign skiers.

Now we have discussed the importance of snow tourism, we will proceed to evaluate its economic sustainability. The main objective of this paper is to use economic and financial analysis to analyse the profitability and financial structure of the main ski resorts in Austria, France, and Italy, and to determine which ski resorts are better prepared to undertake the necessary investment to overcome the threat of climate change without compromising economic viability. In addition, we examine the determinants of the rate of profit with a particular focus on size, elevation, and being part of a larger group.

Consequently, the present work covers an important gap in the literature with regard to the economic and financial status of ski resorts, which derives from the difficulty in obtaining the necessary data to carry out an in-depth analysis. To this end, we have analysed the data from the financial statements of the 61 largest lift operators in Austria, France, and Italy in order to explore their economic viability.

\section{Conceptual Background}

Although climate change is only one of the factors that influence winter tourism, the presence or absence of snow (snow depth) and its temporary nature are key elements when assessing profitability and sustainability in the medium and long term [12]. Therefore, one of the biggest problems for ski lift operators in poor winter snow season times is the increased water demand for the snowmaking systems [15]. It is worth recalling that the shortening of the snow season and scarcity of snow at lower altitudes require the use of artificial snow, which means a considerable increase in production costs and water usage [16]. Some authors highlight the difficulty of achieving sustainable development in snow tourism, given that the interests of the different economic agents result in short-term visions that are subject to profitability criteria [16].

In recent years, many studies have shown and corroborated the existence of a global climate change (IPCC) [17], together with economic efficiency, one of the generic factors worthy of consideration with respect to the future of the tourism industry. With respect to this, the literature states that climate change is eroding the efficiency of snow tourism at an alarming rate [18-21]. Studies have argued that in light of predictions of increased temperatures, the production of artificial snow will become less efficient and more expensive over time [16,18,21].

The long-term economic profitability of this practice is therefore brought into question. For ski areas located at low altitudes, the installation of snow cannons derives from a short or medium-term strategy, which is both economically unsustainable and ecologically questionable. Some research has stated that the need to understand differential climate risk grows as investors and financial regulators increasingly require climate risk disclosure at destinations [22]. Another study investigated the socio-economic implications of changes in snow conditions for ski resorts in the French Alps, analysing their economic impact. The results show that snow conditions in ski resorts differ greatly depending on their geographical location, size and altitude [23].

Various studies focusing on the tourism industry have analysed the factors that influence the survival of companies in the hotel accommodation and restaurant sectors [24-27] and the hospitality industry [28]. These studies show that firms' survival is significantly and positively related to their size, 
even if some authors state that performance decreases with size [29]. In the same line, some studies have argued that small firms are more able to innovate because of their flexible structure and more risky behaviour [30]. Despite this, most studies in the literature find that large firms are more efficient than small firms on average, as a consequence of their greater market power, strategic grouping by firms, and economies of scale [31]. In the specific case of winter tourism, an investigation analysing the financial and economic sustainability of ski resorts in the Catalan Pyrenees found that only large ski areas are profitable and the rest are in most cases, not sustainable from a strictly economic point of view [32]. However, the study also revealed that most areas are sustained by the local authorities due to the income generated by their existence. Another work studied the effect of climate change on the economic sustainability of ski resorts based on adaptation costs [33]. The results showed that large investments can reduce the ability to respond to changes quickly, that small businesses are most affected by financial costs, and that seasonality affects the ability to absorb costs incurred adapting to the effects of climate change. Finally, the study also found that the benefits can be worth the costs. Thus, according to the literature, it would seem clear that size also plays an important role in the performance of ski resorts, encouraging more analysis on this aspect.

To date, several studies have analysed the impact of climate change on some of the world's main mountainous regions [34]. Most have focused on the Alps [22,35-37], Canada [38,39], and the US [40,41], although countries like Sweden [19,42], Australia [43,44], Japan [45], Spain [33,46], and New Zealand [47] have also been researched. Despite the limitations and heterogeneity of the methodologies used, most of these studies coincide in pointing out that in the future, climate change will have a negative impact on the length of the ski season, and it will cause a fall in the number of ski areas and skiers at both low altitude and low latitude. Given this situation, there is good reason to conduct an analysis of the profitability of the main ski resorts at a European level in order to determine whether these resorts are sustainable from an economic viewpoint.

\section{Ski Resorts and Economic Sustainability}

The literature states that an economically sustainable company guarantees sufficient cashflow to ensure liquidity at any time, while producing a persistent above-average return to its shareholders [48]. The same would be true of ski resorts. In order to analyse the profitability and proper functioning of any sector of activity, the literature commonly makes use of the economic and financial data of the companies comprising it, applying a great diversity of statistical techniques, such as models for evaluating efficiency or business survival models, among many others. Numerous examples of this type of study have been applied to the financial sector [49-51], the hospital sector [52], and the electrical industry [53], among others. The tourism industry is no exception, studies having analysed the efficiency of travel agencies [54-56], the hotel sector [57-60], airports [61,62], and restaurants [63], among other subsectors of activity. Profitability is commonly regarded as a measure of economic sustainability of tourism enterprises [64]. Another common measure of economic sustainability is debt ratio, which is the portion of a company's assets that is financed through debt. A high debt ratio often reflects cumulated losses in the past, and could determine a company's capacity to make new investments in the future.

However, there is scant evidence of work focusing on the productivity and economic status of ski resorts in the literature. In this respect, it is worth highlighting one study that compares the efficiency of the ski resort conglomerates (SRC) with the independent ski resorts in four countries (Canada, France, the United States, Switzerland) for the 2005/2006 season, using a stochastic frontier model [11]. The study found that certain SRCs (those managed by the Intrawest Group) proved to be more efficient than independent ski resorts, although these differences did not apply to other SRCs. Another piece of research analysed the productivity of French ski resorts for the period 2008-2010 through the Luenberger productivity indicator (LPI), based on the directional distance function [65]. The study found that productivity fell in most French ski resorts, and that larger ski resorts were more efficient than smaller ones. These two studies therefore feed the hypothesis that size can be a decisive 
factor in the performance of ski resorts, the justification for which would be a better use of resources (economies of scale), as well as the greater attraction of large-scale resorts, where a high number of pistes and skiable kilometres are arguments commonly used in marketing and communication campaigns [65].

We also found research that analyses the relationship between a resort's environmental strategies and financial performance through the concept of technical efficiency [4]. The results of this study show that citizen awareness is more efficient than the company's environmental strategies. Finally, it is also worth mentioning a work that analysed the survival of ski lift companies in Austria for the period 1995-2011 [66]. Using both Cox proportional hazard and competing risk models, the author found that early installation of snow production equipment represented a lower risk of failure for these companies, while its later installation had no influence. Other variables such as size and altitude, local competition, and regional effects were also found to play a significant role in ski areas' survival.

It should be noted that these studies took more technical aspects of ski resorts (altitude, number of pistes, skiable kilometres, number of skiable days, etc.) into account in their respective analyses, without analysing the economic aspects reflected on their balance sheets and income statements. We can therefore state that there is an important gap in the literature regarding the analysis of ski resorts' economic status. This lack of research is undoubtedly due, as pointed out by the aforementioned authors, to the scarcity of available data to allow a proper analysis. It is precisely this lack of data, in relation to both the number of ski resorts with available data and the information available for each ski resort, that discourages the use of certain more complex statistical techniques-which require a greater volume of data-and leads us to use ratio analysis in this work. However, the use of ratios is not new in this field, since previous studies have used them to analyse the situation of alpine ski resorts in Catalonia [33,67]. An analysis using ratios presents some advantages over other more complex analytical techniques, including the fact that it is easier to use and allows easy interpretation of the results. In addition, it also allows companies to be compared even when their annual accounts are expressed in different currencies. Comparison by means of average ratios is very useful for diagnosing problems; for example, a company having a much lower profitability ratio than that of the other companies in the sector could be an indicator of problems of efficiency and/or competitiveness [68]. In addition, the determinants of the profit rates are analysed. A special focus is on size, height, and being part of a larger group.

\section{Data}

To carry out the study, we selected a sample of ski resorts from three different countries: Austria, France and Italy. These countries were chosen because they represent the largest number of ski resorts in Europe, and due to the weight of this sector in their economies. As a period of study, we selected an interval of five years, between 2012 and 2016, since by that time, the international financial crisis was considered to be over and economic growth had recovered.

The economic and financial data for the ski resorts in the sample were obtained from the Orbis database, developed by Bureau Van Dijk, which includes more than 144 million companies worldwide and provides data in a standardized format, making it possible to conduct a comparison between countries.

When identifying ski resorts in any database, one problem that arises is the absence of a single epigraph for this type of activity in the European Community's Statistical Classification of Economic Activities (NACE Rev. 2), which makes it impossible to obtain a single list of all ski resorts included in the database. However, following an individual search resort by resort, we verified that most of the ski resorts we had identified manually were included under the following activity headings:

NACE REV.2-9311. Management of sports facilities.

NACE REV.2-4931-Urban and suburban passenger land transport.

We therefore filtered the companies in the database, selecting those companies whose (main or secondary) activity was one of the above. Subsequently, an individual review was carried out 
to identify which of these companies were ski resorts, the rest being discarded. Finally, and given that some ski resorts are not included under these activity headings, we conducted a new search of the database, taking into account the description of the activity provided for each company in the Orbis database, and selecting those companies in which the description included the word "ski". Subsequently, a new individual review was carried out to identify the ski resorts and to discard the rest. Following this identification process, we obtained a total sample of 61 ski resorts for which data were available for the period of study. Appendix A shows the complete list of ski resorts included in the sample. The Appendix also states whether the ski lift elevators belong to a larger business group, and also their maximum elevation. As we can see, the sample consists of high-elevation ski areas, so it is not representative of the ski industry as a whole. Appendix B shows the distribution of resorts by country and size.

The country with most ski resorts in the sample was Austria (37.7\% of the total), followed by France $(34.4 \%)$, and then Italy (27.9\%). By size, the reduced relative number of small ski resorts indicated that the sample was biased towards large firms. This was due to the database used (Orbis) not representing the group of small ski lift operators, who do not have to provide a detailed profit and loss statement.

The largest resorts were concentrated mainly in France (five of the seven in the sample), which had a lower proportion of smaller resorts than the other two countries. By contrast, none of the resorts in the Italian sample fit the large category, and almost half were classified as small, giving an idea of the smaller size of ski resorts in that country. These findings are confirmed if we look at Appendix C, where we see the average volume of assets and average turnover for each country over the period.

We observed that the French resorts were significantly larger than the Austrian and Italian ones, both in terms of volume of assets and turnover, with the latter being the smallest. However, we should take into account that this sample was not representative of all ski resorts in these countries, especially regarding small ski lift operators. The results and interpretations drawn from this study should therefore be taken with caution, since they do not fully reflect the real presence of large, medium-sized, and especially small ski resorts in these countries.

Finally, we also observe that ski resorts in all three countries increased in average size, in terms of volume of assets over the period analysed, although these increases were more noticeable in the Austrian and French resorts, and smaller in the Italian ones. These increases were also visible in average turnover, although the Italian resorts experienced a slight fall in 2016.

\section{Economic and Financial Analysis}

\subsection{Profitability Analysis}

In order to determine the economic situation of the ski resorts in the three countries in the sample, we applied a set of economic ratios.

\subsubsection{Economic Profitability}

The economic profitability or ROA (return on assets) was calculated as the EBIT (earnings before interest and taxes) generated by the company in relation to the investment made to obtain them, or the total assets. Table 1 shows the average levels of economic profitability obtained for each country.

As we can see, the French ski resorts obtained the highest average profitability for all years analysed (the differences being statistically significant), followed by the Austrian and the Italian ones, the latter having the lowest levels of economic profitability (with the exception of 2016). These results could be justified by the fact that, as we have already seen, the French resorts included in the sample were larger on average, with the Italian ones being the smallest. And, as we have gleaned from the literature $[13,65]$, a greater size could contribute to ski resorts obtaining better economic results.

In order to corroborate the above hypothesis, the average economic profitability was calculated by size of resort. Table 2 shows that the average economic profitability of the resorts analysed was positive 
in all periods, and that there was also a direct relationship between profitability and size. The largest resorts were those that were more economically profitable, and vice versa. In addition, we could see that the smallest ski resorts were the least economically profitable in a statistically significant way.

Table 1. Evolution of economic profitability (return on assets, ROA) by country (percent).

\begin{tabular}{|c|c|c|c|c|c|}
\hline AUSTRIA & 2016 & 2015 & 2014 & 2013 & 2012 \\
\hline Mean & 5.07 & 5.27 & 5.57 & 6.11 & 5.49 \\
\hline Min & -1.96 & -3.64 & -4.11 & -1.67 & -6.64 \\
\hline Max & 12.64 & 12.60 & 12.59 & 12.91 & 11.86 \\
\hline Dev. & 0.0389 & 0.0439 & 0.0425 & 0.0425 & 0.0506 \\
\hline Median & 4.94 & 4.60 & 5.71 & 5.53 & 7.63 \\
\hline FRANCE & 2016 & 2015 & 2014 & 2013 & 2012 \\
\hline Mean & 6.74 & 7.59 & 7.02 & 7.95 & 6.86 \\
\hline Min & -0.12 & 1.09 & 2.21 & 2.03 & -2.79 \\
\hline Max & 18.99 & 21.77 & 18.52 & 17.69 & 16.16 \\
\hline Dev. & 0.047 & 0.056 & 0.047 & 0.043 & 0.050 \\
\hline Median & 5.16 & 4.93 & 5.13 & 7.40 & 6.54 \\
\hline ITALY & 2016 & 2015 & 2014 & 2013 & 2012 \\
\hline Mean & 6.58 & 3.44 & 3.27 & 2.73 & 3.29 \\
\hline Min & 0.46 & -8.81 & -0.37 & -1.27 & -3.16 \\
\hline Max & 40.50 & 18.94 & 12.83 & 10.66 & 12.33 \\
\hline Dev. & 0.099 & 0.062 & 0.041 & 0.036 & 0.044 \\
\hline Median & 3.04 & 2.98 & 1.62 & 2.46 & 1.73 \\
\hline \multicolumn{6}{|c|}{ ANOVA } \\
\hline $\mathrm{ROA}$ & $\begin{array}{c}\mathrm{F} \\
9.70\end{array}$ & $\begin{array}{c}p \text { value } \\
0.000\end{array}$ & & $\begin{array}{l}\text { key meth } \\
\text { Austria }\end{array}$ & \\
\hline
\end{tabular}

* The main ROA value is significantly higher in the French ski resorts. The $\sim$ sign indicates statistically non-significant differences.

Table 2. Evolution of economic profitability (ROA) by size (percent).

\begin{tabular}{cccccc}
\hline LARGE & $\mathbf{2 0 1 6}$ & $\mathbf{2 0 1 5}$ & $\mathbf{2 0 1 4}$ & $\mathbf{2 0 1 3}$ & $\mathbf{2 0 1 2}$ \\
\hline Mean & 7.39 & 7.18 & 6.94 & 7.27 & 7.17 \\
Min & 4.71 & 4.60 & 4.11 & 2.03 & 2.56 \\
Max & 12.69 & 13.63 & 11.03 & 11.91 & 11.85 \\
Dev. & 0.0302 & 0.0361 & 0.0294 & 0.0366 & 0.0351 \\
Median & 7.15 & 4.91 & 5.39 & 6.93 & 6.57 \\
\hline MEDIUM-SIZED & $\mathbf{2 0 1 6}$ & $\mathbf{2 0 1 5}$ & $\mathbf{2 0 1 4}$ & $\mathbf{2 0 1 3}$ & $\mathbf{2 0 1 2}$ \\
\hline Mean & 7.18 & 6.90 & 5.70 & 6.45 & 5.43 \\
Min & -1.96 & -3.64 & -4.11 & -1.67 & -6.64 \\
Max & 40.50 & 21.77 & 18.52 & 17.69 & 16.16 \\
Dev. & 0.0775 & 0.0601 & 0.0498 & 0.0509 & 0.0561 \\
Median & 4.86 & 5.36 & 4.46 & 5.53 & 6.41 \\
\hline SMALL & $\mathbf{2 0 1 6}$ & $\mathbf{2 0 1 5}$ & $\mathbf{2 0 1 4}$ & $\mathbf{2 0 1 3}$ & $\mathbf{2 0 1 2}$ \\
\hline Mean & 3.47 & 2.47 & 4.37 & 4.09 & 4.53 \\
Min & 0.46 & -8.81 & -0.37 & -1.27 & -3.16 \\
Max & 7.81 & 9.36 & 14.01 & 9.69 & 12.33 \\
Dev. & 0.0226 & 0.0401 & 0.0421 & 0.0335 & 0.0420 \\
Median & 2.85 & 2.47 & 2.86 & 3.77 & 3.57 \\
\hline \multicolumn{7}{c}{ ANOVA } & \multicolumn{2}{c}{ Tukey method } \\
\hline ROA & 8.34 & $p$ value & & \\
\hline
\end{tabular}

* The main ROA value is significantly lower in small ski resorts. The $\sim$ sign indicates statistically non-significant differences. 
Alpine ski resorts are characterized by intensive activity with regard to fixed costs [67] because practically all of their assets are non-current, and structural costs are usually very high. Thus, costs such as personnel, depreciation charges or other operating expenses usually represent a very significant weight on the income statement. A previous study that analyses the economic sustainability of Catalan alpine ski resorts [33] shows how the weight of depreciation can in some cases reach percentages of up to $99.16 \%$ of the sales figure, personnel expenses up to $67 \%$, and other operating expenses, where energy consumption is included, up to $69.16 \%$.

This characteristic means that ski resorts have significant economic leverage; that is, when there is a percentage increase or decrease in their sales, the percentage increase or decrease in operating profit is several times higher due to the "leverage" effect exerted by fixed or structural costs. We therefore see how, for ski resorts, average economic profitability will be greater with a larger company size, thanks to a greater use of the economies of scale.

In order to carry out a more detailed analysis of economic profitability (ROA), and following the Dupont model [69], we calculated the two factors that contributed to it: margin and asset rotation.

Sales Margin

The sales margin was calculated as the EBIT, obtained in relation to sales figures for one year. Table 3 shows the average margins if the resorts are classified according to size, with the largest resorts obtaining the largest margins and the medium-sized and smaller ones obtaining similar levels.

Table 3. Average margins by size (percent).

\begin{tabular}{cccccc}
\hline Size & 2016 Margin & 2015 Margin & 2014 Margin & 2013 Margin & 2012 Margin \\
\hline Large & 18.31 & 17.36 & 17.48 & 18.09 & 17.51 \\
Medium-sized & 14.86 & 14.20 & 12.35 & 13.56 & 10.78 \\
Small & 12.06 & 8.03 & 12.98 & 12.74 & 12.58 \\
\hline
\end{tabular}

One might think that the larger resorts can establish higher sales prices due to their greater commercial attractiveness (skiable kilometres, number of pistes, number of lifts, or other services). Furthermore, the greater use of economies of scale also allows their average costs to be lower.

Asset Turnover

Asset turnover, or the number of times that the investment or asset is transformed into a sales figure in a year, was very low for all seasons (Table 4). These results were consistent with the findings of another piece of research focused on Catalan alpine ski resorts, observing that asset turnover contributes less than sales margin to economic profitability [33]. This result is completely logical, since the resorts need to make a large investment in fixed assets or infrastructure to conduct their activity, and turnover is therefore lower. However, medium-sized resorts obtain slightly better results than the others.

Table 4. Asset turnover by size.

\begin{tabular}{cccccc}
\hline Size & 2016 Turnover & 2015 Turnover & 2014 Turnover & 2013 Turnover & 2012 Turnover \\
\hline Large & 0.42 & 0.42 & 0.41 & 0.41 & 0.41 \\
Medium-sized & 0.45 & 0.52 & 0.53 & 0.53 & 0.49 \\
Small & 0.29 & 0.33 & 0.30 & 0.30 & 0.30 \\
\hline
\end{tabular}

We have shown that sales margin is the factor that contributes most to obtaining economic profitability, while asset turnover has a minimal effect, a common result in sectors that require large infrastructures. This fact favours the larger ski resorts because they work with higher margins, as we have seen previously. 


\subsubsection{Financial Profitability}

ROE (return on equity) was calculated as net profit in relation to the owners' resources contributed to the company. Table 5 shows the average financial return obtained by the ski resorts by country. The results coincided with those obtained previously for returns on assets. That is to say, the French ski resorts analysed obtained the highest average financial return in all of the years analysed, followed by Austria and Italy, the latter again being the one that tended to present lower levels of financial profitability (with the exception of 2016). In addition, the differences between the French and Italian ski resorts were statistically significant. Therefore, these findings corroborate the fact that the French resorts included in the sample (the largest ones) were those with the highest average profitability. We should again note that these results should be taken with caution because of the low degree of representativeness of the sample (especially regarding small ski resorts).

Table 5. Average return on equity (ROE) by country (percent).

\begin{tabular}{cccccc}
\hline AUSTRIA & $\mathbf{2 0 1 6}$ & $\mathbf{2 0 1 5}$ & $\mathbf{2 0 1 4}$ & $\mathbf{2 0 1 3}$ & $\mathbf{2 0 1 2}$ \\
\hline Mean & 5.72 & 5.33 & 5.74 & 4.40 & 2.56 \\
Min & -7.82 & -7.77 & -6.64 & -51.14 & -77.87 \\
Max & 21.68 & 22.88 & 18.43 & 27.24 & 21.32 \\
Dev. & 0.0630 & 0.0679 & 0.0586 & 0.1476 & 0.1999 \\
Median & 5.48 & 5.37 & 6.15 & 6.52 & 6.28 \\
\hline FRANCE & $\mathbf{2 0 1 6}$ & $\mathbf{2 0 1 5}$ & $\mathbf{2 0 1 4}$ & $\mathbf{2 0 1 3}$ & $\mathbf{2 0 1 2}$ \\
\hline Mean & 7.50 & 8.57 & 6.95 & 7.88 & 5.58 \\
Min & 1.98 & 2.05 & -2.71 & -2.54 & -19.76 \\
Max & 15.42 & 37.61 & 15.37 & 15.34 & 14.45 \\
Dev. & 0.0357 & 0.0761 & 0.0406 & 0.0445 & 0.0886 \\
Median & 7.07 & 6.51 & 6.92 & 8.07 & 9.33 \\
\hline ITALY & $\mathbf{2 0 1 6}$ & $\mathbf{2 0 1 5}$ & $\mathbf{2 0 1 4}$ & $\mathbf{2 0 1 3}$ & $\mathbf{2 0 1 2}$ \\
\hline Mean & 7.39 & 4.60 & 1.79 & 1.12 & 1.45 \\
Min & -0.69 & -5.17 & -13.35 & -6.77 & -9.05 \\
Max & 54.48 & 52.07 & 11.74 & 9.72 & 10.48 \\
Dev. & 0.1343 & 0.1360 & 0.0555 & 0.0449 & 0.0512 \\
Median & 3.34 & 1.37 & 1.28 & 0.37 & 1.08 \\
\hline & & ANOVA & & & \\
\hline ROE & F & $p$ value & & Tukey method & \\
\hline
\end{tabular}

* The main ROA value is significantly higher in French ski resorts compared to Italian ones. There are no significant differences between the Austrian ski resorts and the others.

Following the previous analysis, and to again verify the relationship between profitability and size, financial profitability was calculated according to the size of the resorts in the sample (Table 6).

On this occasion, we saw how large and medium-sized resorts obtained very similar financial returns, while the smaller ones obtained the lowest average net profit in relation to the funds contributed by their owners. However, in this case, the differences between the three groups were not statistically significant.

Profitability levels are a good indicator of both the ski resorts' current situation and their future economic sustainability. However, the latter concept is much more complex, because a ski resort must not only be able to obtain profits in the present, but also be able to generate them in the future, which will require constant adaptation to the environment. Specifically, taking into account the current situation and future prospects, changes in climate will force ski resorts to make major investments in order to adapt to new weather conditions. Therefore, it is important to also determine their financial situation regarding possibilities for growth and investment in the immediate future. In the next section, we proceed with an analysis of this financial dimension. 
Table 6. Average ROE by size (percent).

\begin{tabular}{cccccc}
\hline LARGE & $\mathbf{2 0 1 6}$ & $\mathbf{2 0 1 5}$ & $\mathbf{2 0 1 4}$ & $\mathbf{2 0 1 3}$ & $\mathbf{2 0 1 2}$ \\
\hline Mean & 7.48 & 6.65 & 6.86 & 7.21 & 7.23 \\
Min & 4.15 & 3.84 & 3.34 & 0.27 & 3.31 \\
Max & 11.37 & 11.03 & 10.44 & 11.33 & 11.98 \\
Dev. & 0.0290 & 0.0273 & 0.0267 & 0.0366 & 0.0322 \\
Median & 6.76 & 5.43 & 6.15 & 7.19 & 6.60 \\
\hline MEDIUM-SIZED & $\mathbf{2 0 1 6}$ & $\mathbf{2 0 1 5}$ & $\mathbf{2 0 1 4}$ & $\mathbf{2 0 1 3}$ & $\mathbf{2 0 1 2}$ \\
\hline Mean & 8.01 & 7.92 & 5.52 & 5.10 & 2.01 \\
Min & -7.82 & -7.77 & -6.64 & -51.14 & -77.87 \\
Max & 54.48 & 52.07 & 18.43 & 27.24 & 16.64 \\
Dev. & 0.1015 & 0.1155 & 0.0575 & 0.1225 & 0.1669 \\
Median & 6.66 & 5.69 & 5.37 & 7.25 & 4.83 \\
\hline SMALL & $\mathbf{2 0 1 6}$ & $\mathbf{2 0 1 5}$ & $\mathbf{2 0 1 4}$ & $\mathbf{2 0 1 3}$ & $\mathbf{2 0 1 2}$ \\
\hline Mean & 4.16 & 2.94 & 3.50 & 3.04 & 4.34 \\
Min & -0.71 & -5.17 & -13.35 & -6.77 & -9.05 \\
Max & 11.40 & 11.44 & 11.97 & 9.84 & 21.32 \\
Dev. & 0.0322 & 0.0433 & 0.0578 & 0.0498 & 0.0705 \\
Median & 3.91 & 3.35 & 3.79 & 4.06 & 3.96 \\
\hline \multicolumn{7}{c}{ ANOVA } & \multicolumn{3}{c}{ Tukey method } \\
\hline ROE & F & $p$ value & & \\
\hline & 2.03 & 0.133 & There are no significant differences between the three groups considered. & \\
\hline
\end{tabular}

\subsection{Financial Analysis}

In order to determine the ski resorts' financial situation as companies, we calculated their debt ratio. The debt ratio was calculated as the total debts a company has in relation to its equity. Ideally, the result of this ratio is as small as possible, to allow the company greater financial autonomy. Or, to put another way, it will make the company less dependent on banks when carrying out its business. Table 7 shows the results obtained for the ski resorts analysed according to size.

Table 7. Indebtedness by size.

\begin{tabular}{cccccc}
\hline Size & $\begin{array}{c}\text { Indebtedness } \\
\mathbf{2 0 1 6}\end{array}$ & $\begin{array}{c}\text { Indebtedness } \\
\mathbf{2 0 1 5}\end{array}$ & $\begin{array}{c}\text { Indebtedness } \\
\mathbf{2 0 1 4}\end{array}$ & $\begin{array}{c}\text { Indebtedness } \\
\text { Indebtedness }\end{array}$ & $\begin{array}{c}\text { 2013 } \\
\mathbf{2 0 1 2}\end{array}$ \\
\hline Large & 0.67 & 0.64 & 0.71 & 0.73 & 0.73 \\
Medium-sized & 1.14 & 1.28 & 1.37 & 1.19 & 1.57 \\
Small & 1.23 & 1.12 & 1.18 & 1.31 & 1.34 \\
\hline
\end{tabular}

As we can see, the larger resorts displayed lower levels of debt than the others. This characteristic can give them a greater margin to undertake new investments in the future. The fact of being less indebted can on the one hand gives them more facilities to obtain additional external financing (given their greater level of capitalization), and on the other, the possibility of increasing the proportion of indebtedness in relation to their own resources, without losing financial balance.

In summary, we observed that although on average, the resorts analysed in this study presented positive results and an adequate financial structure, it was the companies of greater size that presented better future prospects by obtaining higher returns and having greater financial autonomy, which would allow them to make the future investments necessary to adapt to the new conditions of the sector. 


\subsection{Regression Analysis}

The univariate analysis has given us a first idea regarding the operations of ski resorts in Austria, France and Italy, by both country and size. However, economic and financial profitability measures are much more complex variables that may be affected by other factors. This must be taken into account if we are to isolate the effects that characteristics such as size or country have on profitability. Thus, a univariate analysis is not enough to draw solid conclusions.

Therefore, in this last section, and in order to endow the study with greater robustness, we performed a regression analysis that allowed us to validate the results and conclusions reached in the previous sections regarding the relationship between the size of the ski resorts and their economic and financial performance.

In this regression analysis, we took the financial performance measures of the ski resorts as a dependent variable. That is to say, we estimated a first regression model, taking economic profitability (ROA) as a dependent variable, and a second where we took financial profitability (ROE) as a dependent variable.

In both cases, we took into consideration the following as independent variables:

- Size: Calculated as the natural logarithm of all assets of the company so as to minimize the asymmetry of the variable given its great variability. Prior studies have previously related the size of ski resorts to their operation $[13,65]$, arguing that size can generate higher returns due to a better use of the available financial and marketing resources. It must be taken into account that size can be defined in many ways. A narrow measure is based on the asset value, turnover, or employment of the operator itself. A wider measure is based on the size of the ski destination, including all ski lift operators that comprise this network (linked by ski lift or ski-run). In this study, ski lift operators were treated as independent firms; links with neighbouring operators were not accounted for because we did not have data for all ski lift operators in each ski network. This was a limitation that could make it difficult to interpret differences in size.

- Elevation: Calculated as the natural logarithm of the ski resorts' maximum elevation so as to minimize the asymmetry of the variable caused by its great variability. Prior studies have shown that ski resorts located at low altitudes will be more affected by climate change [69]. This would be justified both by the reduction in the number of visitors (something that has already been observed in Austria [70]) and by the higher costs associated with manufacturing snow. Therefore, a ski resort's elevation can play an important role in its economic performance, and this variable must be included in the model.

- Being part of a larger group: Dichotomous variables that takes the value 1 when the analysed ski resort belongs to a group, and 0 when it is an independent resort. In line with this, [13] observed that ski resorts belonging to a certain group can sometimes be more efficient than independent resorts, although for most of the analysed groups, no significant differences were observed. A positive influence may be expected from this variable, due to resorts belonging to a group having better access to financial and marketing resources [71].

- Country: Three dummy variables corresponding to the respective countries included in the study (Austria, France, and Italy) were incorporated into the model, with the aim of capturing the effect of country on profitability. In this respect, the variable "Austria" took the value 1 if the observation corresponded to an Austrian ski resort, and 0 otherwise, and likewise with the variables "France" and "Italy". As a result, the regression coefficients for these variables represented the differential effects of each country on the dependent variable when compared to the group taken as a reference (we took the Austrian ski resorts as a reference group as they were the most numerous in the sample). Despite being neighbouring European countries, the three had their own macroeconomic and weather conditions that could influence the ski resorts' activity (number of skiers/year, level of expenditure, number of days open, etc.), meaning the inclusion of this variable in the regression was more than justified. 
The regression model proposed therefore took the following form:

Profitability indicator $=\beta_{0}+\beta_{1}$ SizeEj $+\beta_{2}$ Elevationj $+\beta_{3}$ Part of a larger groupj $+\beta_{4-6}$ Countryj $+\varepsilon j$

where the profitability indicator represents ROA or ROE; j denotes the ski lift operator, and $\varepsilon$ represents the random error term.

The results obtained from estimating the previous model are shown in Table 8 (taking ROA as an independent variable) and in Table 9 (taking ROE as an independent variable).

Table 8. Regression results for economic profitability (ROA)

\begin{tabular}{|c|c|c|}
\hline \multicolumn{3}{|c|}{ Coefficients } \\
\hline Term. & Coef. & $\mathbf{T}$ \\
\hline Constant & 0.055 & 0.51 \\
\hline Size (ln book value of total assets) & $0.008 * *$ & 2.47 \\
\hline Large group & $0.010 *$ & 1.81 \\
\hline Max. Elevation & -0.008 & -0.54 \\
\hline France & $-0.031 * * *$ & -4.31 \\
\hline Italy & $-0.028^{* * *}$ & -3.63 \\
\hline \multicolumn{3}{|c|}{ Regression summary } \\
\hline \multicolumn{3}{|c|}{ R-sq. $=0.177$ R-sq. (adjusted) $=0.161$} \\
\hline \multicolumn{3}{|c|}{ Austria taken as a reference country } \\
\hline \multicolumn{3}{|c|}{ Significance levels: $1 \%\left({ }^{* * *}\right) ; 5 \%\left({ }^{* *}\right) ; 10 \%\left({ }^{*}\right)$} \\
\hline \multicolumn{3}{|c|}{ Regression estimated using ordinary least squares (OLS) } \\
\hline
\end{tabular}

Table 9. Regression results for financial profitability (ROE).

\begin{tabular}{|c|c|c|}
\hline \multicolumn{3}{|l|}{ Coefficients } \\
\hline Term. & Coef. & $\mathbf{T}$ \\
\hline Constant & 0.032 & 0.24 \\
\hline Size (ln book value of total assets) & $0.017^{* * *}$ & 4.07 \\
\hline Large group & 0.009 & 1.3 \\
\hline Max. Elevation & -0.018 & -0.96 \\
\hline France & $-0.032 * * *$ & -3.77 \\
\hline Italy & $-0.034 * * *$ & -3.69 \\
\hline $\begin{array}{r}\text { Reg } \\
\text { R-sq. }=0.16 \\
\text { Austria tak } \\
\text { Significance le } \\
\text { Regression estimated }\end{array}$ & $\begin{array}{l}\text { summary } \\
\text { (adjusted) }= \\
\text { reference co } \\
o(* * *) ; 5 \%(* * \\
\text { ordinary leas }\end{array}$ & \\
\hline
\end{tabular}

As we can see, there was a statistically significant positive relationship (at 5\% significance) between a ski resort's size and its economic profitability, revealing that the larger the resort, the greater its economic profitability. This result was in line with that observed in the literature [65], where greater operational efficiency was observed among the larger resorts in France. This result was explained by their greater use of economies of scale, and also their better marketing resources, which ultimately led to higher profitability.

On the other hand, a highly significant effect ( $1 \%$ significance) was also observed according to the country in which the ski resorts operated. Specifically, both the variables related to France and Italy showed a negative influence on ROA when taking the Austrian resorts as a reference. This means that once the effect of other variables (such as size) has been isolated, operating in Austria allows ski resorts to enjoy greater economic returns. Previously (Section 5.1.1), we noted higher levels of 
economic profitability in the French ski resorts, which, according to the results, would be explained by their size and other unobserved factors, and not due to their operation in France.

As for belonging to a larger business group, we observed a weak statistically significant (at $10 \%$ significance) effect on economic profitability. Thus, companies belonging to a larger business group seemed to have a small economic advantage due to sharing common resources, both economic and marketing, with other ski lift operators.

Finally, we did not find a statistically significant effect for the elevation of the ski resorts, taking their maximum altitude as a reference. This result was not surprising if we bear in mind that, as noted in the Data section, the sample consisted of high-elevation ski areas, so differences in altitude were not sufficient to generate differences in profitability.

It should be noted that the model could only explain a small proportion of the variation of the profit ratio of ski lift operators (R-sq. adjusted: 0.161 ), so some other variables were omitted from this model that explained the main variation in the profit ratio. This was a limitation that should be taken into account when interpreting the results.

If we focused on the influence that these same variables exert on the financial profitability (ROE) of the ski resorts (Table 9), we observed that the influence exerted by size is even stronger, being positive and statistically significant at a $1 \%$ significance. Therefore, the results again showed how a greater size of resort contributes to it being able to obtain higher returns.

As for the influence of country, we observe a highly significant relationship (1\% significance) for the variables corresponding to France and Italy, this influence being negative in both cases. This means that, once the effect of other variables was isolated, the location of operation in France or Italy tended to result in ski resorts obtaining lower levels of financial profitability when compared with ski resorts operating in Austria (with the country taken as a reference). Previously, we observed higher returns in French ski resorts when compared to Italian ones. However, here we did not find significant differences between these two countries, meaning that differences would again be explained more by the size of the resorts analysed in both countries and other factors not considered here, than by the location of operation in one country or the other.

As for the rest of the variables, we observed that neither the ski resorts' altitude nor belonging to a group exerted a statistically significant influence on financial profitability. It would therefore seem evident that these variables do not determine the profitability levels of the companies in the sample to the same degree as other characteristics like size, or the country in which they operate.

We also estimated these models using turnover instead of total assets as a proxy for size, and the results obtained were not significantly different.

\section{Conclusions}

In this paper, we have analysed the economic sustainability of the largest ski resorts in Austria, France, and Italy. Despite less snow due to climate change and the subsequent need for resorts to produce artificial snow, the considerable increase in costs, and the reduction in energy and water efficiency, these companies are on average economically sustainable, as our analysis shows.

The study results reveal the existence of a direct and significant relationship between the size of these ski resorts and their profitability, both financial and economic. Thus, a greater size of resort contributes to generating greater profitability. This result would be explained by both technical reasons, such as the greater use of economies of scale, and commercial ones, such as the greater attraction capacity of this type of resort based on the greater number of slopes and skiable kilometres.

From the results obtained, we see that the French ski resorts have the highest average economic profitabilities throughout the analysed period, followed by the Austrian and Italian ones, the latter tending to present lower levels of profitability. 
However, the explanation for these results would appear to be the size of the ski resorts included in the sample for these countries, because after isolating the effect of size in the regression analysis, we have found that economic profitability is higher for ski lift operators in Austria than in France or Italy. Therefore, according to our results, the external conditions in Austria contribute to improving the economic profitability of these resorts.

In relation to financial profitability, the results again show that although the French resorts obtained higher average levels of financial profitability for all the years analysed; this would be due to the greater size of the French ski resorts included in the sample compared to those in the other two countries. Once the effect of size is isolated (significant result) in the regression, operating in France (or in Italy) has a negative impact on financial profitability, a fact that again reveals the influence of size on these financial indicators.

Furthermore, we also analysed the future financial perspectives of these resorts with regard to climate change in order to determine their possibilities for growth and investment in the immediate future. The results show that despite all of the analysed resorts having an adequate financial structure on the whole, the larger ones have lower levels of indebtedness, and therefore enjoy a greater financial autonomy that gives them greater capacity to undertake new investments without fear of losing their financial balance.

In contrast, the smaller resorts are the ones with a more uncertain future. Their sustainability will therefore need to be assessed, as resorts are not only profitable for themselves, but also have influence in the surrounding territory. They promote the profitability of other local businesses, such as restaurants, commerce, hotels, training companies, and complementary activities, generating jobs and acting as economic engines. However, these complementary activities can only exist if the winter seasons are long and allow the practice of winter sports.

Although municipalities with ski resorts have seen their populations increase, their primary sector assets have declined. This creates a certain dependence on the services sector, which may be endangered in the medium term due to a shortened ski season. Conflict between tourism and primary activities poses a large problem for sustainable development, which needs to be based on a complementary relationship between the two. If tourism activities harm the primary sector in the medium term, natural resources will be lost, leading to the degradation of the landscape.

In short, based on the results of this study and with the limitations deriving from the sample used, we can deduce that in most cases and depending on size, maintaining these ski resorts is a sustainable proposition from a strictly economic point of view, and an uncertain one from an environmental point of view. Public administrations will have to evaluate their sustainability due to the income that they generate, and the positive externalities that they create in the territories where they are located.

It is recommended that both private agents and public administrations should implement strategies to diversify the products and services on offer, including the creation of winter leisure adventure parks, or facilities for specific indoor and outdoor sports, for example. This would maintain the satellite businesses around the current ski resorts, diversify profits, and begin to address the possible losses that may be generated in the future due to the fall in revenue from activities related to snow tourism, activities that once represented economic alternatives for rural areas that were left without a population. Therefore, new formulas must be sought that make tourism compatible with the economic development of the territory, while maintaining the biodiversity and landscape, which are essential requirements for the sustainability of areas where nature is the main resource.

Regarding the limitations of the study, the main limitation is the representativeness of the sample. As noted previously, the database used (Orbis) is not representative of the small ski lift operators group because these companies do not have to provide a detailed profit and loss statement. Thus, the sample is biased towards large firms. For example, although there are around $300 \mathrm{ski}$ lift operators in Austria, we were only able to identify 23 companies in the database, a phenomenon that was also true for French and Italian ski resorts. Consequently, the conclusions cannot be generalized to all ski resorts in these countries. We have also seen that the sample consists of high-elevation ski areas, so 
it is not representative of the ski industry as a whole. This limitation has also forced us to treat ski lift operators as independent firms, without accounting for links with neighbouring operators, which makes it difficult to interpret size differences. Finally, our model can only explain a small proportion of the variation in ski lift operators' profit ratio, which means there are other highly influential variables that have not been included in the sample. In spite of these limitations, this paper provides a first approximation of the differences that could exist between ski resorts by country and size.

As a future line of research, these other influential variables must be identified in order to validate the results obtained in this study. We would also point out that the ski resorts studied were located in three countries belonging to a specific geographical area. As future line of research, it is also proposed that ski resorts be incorporated from other countries so as to have more data and to be able to compare results. Another line of research could be to analyse how climate change will affect the economic efficiency of such areas, and which new costs will be necessary if resorts are to continue to offer this type of tourism activity.

For future research, the inclusion of new countries and a greater number of ski resorts would allow for more complex statistical techniques to be implemented, which were discarded in this study due to the scarcity of data. This would allow the conclusions reached in this study to be verified, analysing factors such as the productivity, efficiency, and survival of ski resorts in addition to their profitability and financial structure.

Author Contributions: All authors collaborated equally. Conceptualization, J.M.-G., L.S.-P. and N.D.; Methodology, J.M.-G. and L.S.-P.; Software, N.D. and E.C.-F.; Validation, N.D.; Formal Analysis, L.S.-P. and J.M.-G.; Investigation, N.D.; Data Curation, J.M.-G. and L.S.-P.; Writing-Original Draft Preparation, N.D.; Writing-Review \& Editing, Eduard Cristobal; Supervision, Eduard Cristobal and J.M.-G.

Funding: This work was supported by the Spanish Ministry of Economy, Industry and Competitiveness [Grant id.: TURCOLAB ECO2017-88984-R].

Acknowledgments: The authors acknowledge the support of the Catalan Government for the accreditation as Consolidated Research Group TURESCO (2017 SGR 49). We would also like to thank the valuable comments of both the anonymous referees and the editor Dr. Martin Falk during the review process.

Conflicts of Interest: The authors declare no conflict of interest. 


\section{Appendix A}

Table A1. List of ski resorts analysed by country.

\begin{tabular}{|c|c|c|c|}
\hline Ski Resort & Country & Max Elevation (m) & Large Group \\
\hline Alpendorf Bergbahnen A.G. (Saint Johann-Alpendorf) & Austria & 1800 & Yes \\
\hline Arlberger Bergbahnen Aktiengesellschaft (St. Anton am Arlberg) & Austria & 2811 & No \\
\hline $\begin{array}{c}\text { BBSH Bergbahnen Saalbach-Hinterglemm Gesellschaft M.B.H. (Skicircus Saalbach: } \\
\text { Hinterglemm, Leogang, Fieberbrunn) }\end{array}$ & Austria & 2096 & No \\
\hline Bergbahn Aktiengesellschaft Kitzbühel (Kitzbühel I Kirchberg ski area) & Austria & 2000 & No \\
\hline Bergbahn Brixen im Thale Aktiengesellschaft (SkiWelt Wilder Kaiser-Brixental) & Austria & 1957 & Yes \\
\hline Bergbahnen Aktiengesell-Schaft Wagrain (Wagrain) & Austria & 2000 & No \\
\hline Bergbahnen Flachau Gesellschaft M.B.H. (Flachau-Wagrain) & Austria & 1990 & No \\
\hline Bergbahnen Nassfeld Pramollo AG (Nassfeld-Lake Pressegger See) & Austria & 2200 & No \\
\hline $\begin{array}{l}\text { Bergbahnen Skizentrum Hoch-Zillertal Gesellschaft M.B.H. \& Co. Kommanditgesellschaft } \\
\text { (HochZillertal-Kaltenbach) }\end{array}$ & Austria & 2500 & No \\
\hline Bergbahnen Westendorf Gesellschaft M.B.H. (SkiWelt Westendorf) & Austria & 1957 & Yes \\
\hline Dachstein Tourismus AG (Dachstein West) & Austria & 1620 & No \\
\hline Dorfgasteiner Bergbahnen Aktiengesellschaft (Dorfgastein Ski Resort) & Austria & 2033 & Yes \\
\hline Gasteiner Bergbahnen Aktiengesellschaft (Bad Gastein-SportGastein) & Austria & 2686 & Yes \\
\hline Hochkönig Bergbahnen GMBH (Hochkönig) & Austria & 1900 & Yes \\
\hline Kleinwalsertaler Bergbahn Aktiengesellschaft (Oberstdorf Nebelhorn) & Austria & 2224 & Yes \\
\hline Silvretta Montafon Bergbahnen GMBH (Silvretta Montafon) & Austria & 2430 & No \\
\hline Silvrettaseilbahn Aktiengesellschaft (ISCHGL) (Silvretta Galtür) & Austria & 2295 & No \\
\hline Skilifte Lech Ing.Bildstein Gesellschaft M.B.H. (St. Anton am Arlberg) & Austria & 2811 & Yes \\
\hline Skiliftgesellschaft Soelden-Hochsölden GMBH (Sölden Ski Area) & Austria & 3340 & No \\
\hline Ski-Zürs-AG (Ski Zürs Arlberg) & Austria & 2440 & Yes \\
\hline $\begin{array}{l}\text { Wintersport Tirol Aktiengesellschaft \& CO. Stubaier Bergbahnen Kommanditgesellschaft } \\
\text { (Ski Resort Stubaier Gletscher) }\end{array}$ & Austria & 3212 & No \\
\hline Zauchensee, Liftgesellschaft Benedikt Scheffer GMBH. (Ski Resort Zauchensee/Flachauwinkl) & Austria & 2188 & Yes \\
\hline Zeller Bergbahnen Zillertal GMBH \& CO KG (Zillertal Arena: Hochkimml) & Austria & 2500 & No \\
\hline Compagnie des Alpes S.A. & France & 3523 & Yes \\
\hline Compagnie du Mont-Blanc (Chamonix) & France & 3275 & No \\
\hline Deux Alpes Loisirs & France & 3600 & Yes \\
\hline Domaine Skiable De La Rosiere (Space San Bernardo) & France & 2650 & No \\
\hline Grand Massif Domaines Skiables (Samöens) & France & 2500 & Yes \\
\hline
\end{tabular}


Table A1. Cont.

\begin{tabular}{|c|c|c|c|}
\hline Ski Resort & Country & Max Elevation (m) & Large Group \\
\hline Societe Amenagement Station La Plagne (Paradiski) & France & 3250 & Yes \\
\hline Societe Equip. Contamines Montjoie Hauteville (Les Contamines) & France & 2450 & No \\
\hline Societe Exploi. Telepher Tarentaise Maurienne (Ski Resort Valfréjus) & France & 2737 & No \\
\hline Société Sports et Tourisme a Châtel (Châtel) & France & 2200 & Yes \\
\hline Société d'Aménagement Touristique de l'Alpe d'Huez et des Grandes Rousses (Alpe d'Huez) & France & 3300 & No \\
\hline Société d'Aménagement de Saint Sorlin (Saint Sorlin d'Arves) & France & 2620 & Yes \\
\hline Société d’Economie Mixte Locale des Orres (Les Orres) & France & 2720 & No \\
\hline Société des Remontées Mécaniques les Houches-Saint Gervais (Ski Camp Les Houches) & France & 1900 & No \\
\hline Société des Téléphériques de la Grande Motte (Tignes/Espace Killy) & France & 3450 & Yes \\
\hline Société des Téléphériques de Val d'Isère (Val d'Isère/Espace Killy) & France & 3456 & Yes \\
\hline Societe des Telepheriques d'Orelle (Orelle) & France & 3450 & Yes \\
\hline Société des Téléportes Bettex Mont d’Arbois (Megève Ski Area) & France & 2350 & No \\
\hline Societe Des Trois Vallees-STV ou S3V (Les Trois Vallées) & France & 3230 & Yes \\
\hline Société d'Exploitation de la Vallée des Belleville (St. Martin de Belleville/Le Trois Vallées) & France & 2434 & Yes \\
\hline Société d'Exploitation des Remontées Mécaniques de Morzine-Avoriaz (Avoriaz) & France & 2460 & Yes \\
\hline Telepherique de Morzine Pleney (Morzine) & France & 2466 & Yes \\
\hline Carosello Tonale S.P.A. (Tonale) & Italy & 3000 & Yes \\
\hline Cervino Societa' Per Azioni (Cervinia-Breuil) & Italy & 3500 & Yes \\
\hline Courmayeur Mont Blanc Funivie S.P.A. Siglabile C.M.B.F. S.P.A. (Courmayeur) & Italy & 2755 & No \\
\hline Dantercepies S.P.A. (Cortina d'Ampezzo) & Italy & 2990 & Yes \\
\hline Doleda Impianti Funiviari S.P.A. (Val di Fassa/Carezzo Ski) & Italy & 2337 & Yes \\
\hline Folgariaski S.P.A. (Folgaria) & Italy & 1820 & Yes \\
\hline Funivia Plan de Corones-S.P.A. (Kronplatz Plan de Corones) & Italy & 2275 & Yes \\
\hline Funivia Siusi-Alpe di Siusi Spa (Alpe di Siusi Ski Resort) & Italy & 2000 & Yes \\
\hline Funivie Alpe Cermis-S.P.A. (Alpe Cermis-Cavalese) & Italy & 2267 & Yes \\
\hline Funivie Madonna di Campiglio S.P.A. (Madonna di Campiglio) & Italy & 2580 & No \\
\hline Funivie Monte Bianco S.P.A. & Italy & 3465 & Yes \\
\hline Funivie S.Vigilio di Marebbe S.P.A. (S.Vigilio di Marebbe/Kronplatz) & Italy & 1605 & Yes \\
\hline Funivie Seceda SPA (Val Gardena) & Italy & 2500 & Yes \\
\hline Funivie Valdaora S.P.A. (Olang Valdaora/Kronplatz) & Italy & 2275 & Yes \\
\hline Gitschberg Jochtal S.P.A. (Gitschberg Jochtal) & Italy & 2500 & No \\
\hline Skiarea Valchiavenna S.P.A. (Ski Resort Valchiavenna-Madesimo/Campodolcino) & Italy & 3000 & No \\
\hline Societa' Impianti Turistici-S.I.T.-S.P.A. (Ponte di Legno) & Italy & 3000 & Yes \\
\hline
\end{tabular}




\section{Appendix B}

Table A2. Distribution of the Sample by country and size. In order to classify the ski resorts by size, we adopted the criterion relating to turnover established in the definition of SMEs (Small and medium-sized enterprises) proposed by the European Commission (Annex I of (EU) Regulation No. 651/2014). According to this criterion, a company is considered small if its turnover is between $€ 2$ and $€ 10$ million during the last fiscal year, medium-sized if its turnover is between $€ 10$ and $€ 50$ million, and large if its turnover exceeds $€ 50$ million.

\begin{tabular}{ccccc}
\hline \multicolumn{5}{c}{ Size } \\
\hline Country & Large & Medium-Sized & Small & Total \\
\hline Austria & 2 & 15 & 6 & 23 \\
France & 5 & 12 & 4 & 21 \\
Italy & 0 & 9 & 8 & 17 \\
Total & 7 & 36 & 18 & 61 \\
\hline
\end{tabular}

\section{Appendix C}

Table A3. Total assets and total turnover by country (thousands of Euros).

\begin{tabular}{ccccccccccc}
\hline & \multicolumn{1}{c}{ Assets } & \multicolumn{7}{c}{ Turnover * } \\
\hline AUSTRIA & $\mathbf{2 0 1 6}$ & $\mathbf{2 0 1 5}$ & $\mathbf{2 0 1 4}$ & $\mathbf{2 0 1 3}$ & $\mathbf{2 0 1 2}$ & $\mathbf{2 0 1 6}$ & $\mathbf{2 0 1 5}$ & $\mathbf{2 0 1 4}$ & $\mathbf{2 0 1 3}$ & $\mathbf{2 0 1 2}$ \\
\hline Mean & 74,363 & 67,821 & 64,682 & 61,811 & 58,679 & n.a. ** & 22,092 & 21,790 & 21,294 & 20,517 \\
Min & 20,828 & 16,508 & 16,633 & 15,210 & 15,445 & 7478 & 5374 & 5138 & 4923 & 5990 \\
Max & 284,877 & 265,006 & 258,051 & 239,681 & 222,634 & 75,904 & 73,950 & 72,886 & 68,245 & 64,593 \\
Dev. & 57,230 & 52,483 & 51,127 & 47,694 & 45,041 & 20,720 & 16,721 & 15,841 & 15,571 & 15,015 \\
Median & 54,787 & 50,269 & 48,915 & 46,088 & 42,303 & 22,447 & 15,481 & 16,834 & 15,075 & 15,132 \\
\hline FRANCE & $\mathbf{2 0 1 6}$ & $\mathbf{2 0 1 5}$ & $\mathbf{2 0 1 4}$ & $\mathbf{2 0 1 3}$ & $\mathbf{2 0 1 2}$ & $\mathbf{2 0 1 6}$ & $\mathbf{2 0 1 5}$ & $\mathbf{2 0 1 4}$ & $\mathbf{2 0 1 3}$ & $\mathbf{2 0 1 2}$ \\
\hline Mean & 141,025 & 133,520 & 133,201 & 129,451 & 125,459 & 67,392 & 64,489 & 62,958 & 62,293 & 62,313 \\
Min & 19,093 & 16,943 & 17,334 & 16,526 & 15,493 & 7533 & 7317 & 6840 & 6090 & 5451 \\
Max & $1,505,779$ & $1,451,417$ & $1,481,879$ & $1,459,078$ & $1,443,539$ & 723,197 & 706,827 & 697,309 & 680,028 & 680,254 \\
Dev. & 318,399 & 306,249 & 313,498 & 308,827 & 305,752 & 152,316 & 148,776 & 146,971 & 143,174 & 143,328 \\
Median & 65,377 & 61,730 & 54,166 & 51,106 & 48,928 & 37,570 & 35,615 & 36,825 & 36,242 & 28,372 \\
\hline ITALY & $\mathbf{2 0 1 6}$ & $\mathbf{2 0 1 5}$ & $\mathbf{2 0 1 4}$ & $\mathbf{2 0 1 3}$ & $\mathbf{2 0 1 2}$ & $\mathbf{2 0 1 6}$ & $\mathbf{2 0 1 5}$ & $\mathbf{2 0 1 4}$ & $\mathbf{2 0 1 3}$ & $\mathbf{2 0 1 2}$ \\
\hline Mean & 38,747 & 37,970 & 37,870 & 37,819 & 36,338 & 11,994 & 13,609 & 13,324 & 11,576 & 10,971 \\
Min & 12,767 & 6237 & 4808 & 821 & 821 & 2029 & 2482 & 1947 & 1960 & 1610 \\
Max & 116,181 & 115,035 & 109,215 & 111,090 & 108,273 & 29,942 & 34,231 & 43,089 & 26,536 & 24,144 \\
Dev. & 27,131 & 27,672 & 27,416 & 29,141 & 27,885 & 7139 & 9017 & 10,250 & 7058 & 6184 \\
Median & 28,914 & 30,076 & 27,969 & 29,152 & 30,367 & 10,121 & 9995 & 8879 & 8670 & 8978 \\
\hline * It should be noted that consolidated data were used, so turnover data for ski lift operators also includes sales by \\
restaurants, ski huts, etc. ${ }^{* *}$ The turnover of some Austrian resorts was not available for 2016, meaning the result \\
could not be compared with that of previous years. & & & & & &
\end{tabular}

\section{References}

1. Vanat, L. 2018 International Report on Snow \& Mountain Tourism. Overview of the Key Industry Figures for Ski Resorts. Available online: http:/ / www.vanat.ch/RM-world-report-2018.pdf (accessed on 22 May 2018).

2. Evren, S.; Kozak, N. Competitive positioning of winter tourism destinations: A comparative analysis of demand and supply sides perspectives-Cases from Turkey. J. Destin. Mark. Manag. 2018, 9, 247-257. [CrossRef]

3. Milman, A.; Zehrer, A.; Tasci, A.D. Measuring the components of visitor experience on a mountain attraction: The case of the Nordkette, Tyrol, Austria. Tour. Rev. 2017, 72, 429-447. [CrossRef]

4. Gonçalves, O.; Robinot, E.; Michel, H. Does it pay to be green? The case of French ski resorts. J. Travel Res. 2016, 55, 889-903. [CrossRef] 
5. Mauri, C.; Turci, L. From ski to snow: Rethinking package holidays in a winter mountain destination. Worldw. Hosp. Tour. Themes 2018, 10, 201-210. [CrossRef]

6. Cristobal-Fransi, E.; Daries, N.; Mariné-Roig, E.; Martín-Fuentes, E. Implementation of Web 2.0 in the snow tourism industry: Analysis of the online presence and e-commerce of ski resorts. Span. J. Mark. ESIC 2017, 21, 117-130. [CrossRef]

7. Lasanta, T.; Laguna, M.; Vicente-Serrano, S.M. Do tourism-based ski resorts contribute to the homogeneous development of the Mediterranean mountains? A case study in the Central Spanish Pyrenees. Tour. Manag. 2007, 28, 1326-1339. [CrossRef]

8. Pechlaner, H.; Tschurtschenthaler, P. Tourism policy, tourism organizations and change management in Alpine regions and destinations: A European Perspective. Curr. Issues Tour. 2003, 6, 508-539. [CrossRef]

9. Dornier, R.; Mauri, C. Conclusions: Managing tourism sustainability in mountain destinations. Worldw. Hosp. Tour. Themes 2018, 10, 267-273. [CrossRef]

10. Martínez, T.L.; Vadillo, J.A.; Bellido, N.P. The contribution of a small ski resort to the development of its surrounding area: the case of Valdezcaray (La Rioja). Cuadernos de Turismo 2014, 33, 381-384.

11. Falk, M. A dynamic panel data analysis of snow depth and winter tourism. Tour. Manag. 2010, 31, 912-924. [CrossRef]

12. Cocolas, N.; Walters, G.; Ruhanen, L. Behavioural adaptation to climate change among winter alpine tourists: An analysis of tourist motivations and leisure substitutability. J. Sustain. Tour. 2016, 24, 846-865. [CrossRef]

13. Falk, M. Are multi-resort ski conglomerates more efficient? Manag. Decis. Econ. 2009, 30, 529-538. [CrossRef]

14. Gerbaux, F.; Marcelpoil, E. Gouvernance des stations de montagne en France: Les spécificités du partenariat public-privé. Revue de Géographie Alpine 2006, 94, 9-19. [CrossRef]

15. Rossello-Nadal, J. How to evaluate the effects of climate change on tourism. Tour. Manag. 2014, 42, 334-340. [CrossRef]

16. Damm, A.; Köberl, J.; Prettenthaler, F. Does artificial snow production pay under future climate conditions?-A case study for a vulnerable ski area in Austria. Tour. Manag. 2014, 43, 8-21. [CrossRef]

17. Intergovernmental Panel on Climate Change (IPCC). Climate Change 2014-Impacts, Adaptation and Vulnerability: Regional Aspects; Cambridge University Press: Cambridge, UK, 2014. Available online: https://www.ipcc.ch/pdf/assessment-report/ar5/wg2/ar5_wgII_spm_es.pdf (accessed on 3 May 2018).

18. Beniston, M. Climatic change in mountain regions: A review of possible impacts. Clim. Chang. 2003, 59, 5-31. [CrossRef]

19. Brouder, P.; Lundmark, L. Climate change in Northern Sweden: Intra-regional perceptions of vulnerability among winter-oriented tourism businesses. J. Sustain. Tour. 2011, 19, 919-933. [CrossRef]

20. Hopkins, D.; Maclean, K. Climate change perceptions and responses in Scotland's ski industry. Tour. Geogr. 2014, 16, 400-414. [CrossRef]

21. Morrison, C.; Pickering, C.M. Perceptions of climate change impacts, adaptation and limits to adaption in the Australian Alps: The ski-tourism industry and key stakeholders. J. Sustain. Tour. 2013, 21, 173-191. [CrossRef]

22. Steiger, R.; Abegg, B. The sensitivity of Austrian Ski areas to climate change. Tour. Plan. Dev. 2013, 10, 480-493. [CrossRef]

23. Spandre, P.; François, H.; Morin, S.; George-Marcelpoil, E.; Lafaysse, M. Investigations on socio economic indicators of French Alps ski industry from an explicit spatial modelling of managed snow on ski slopes. In Proceedings of the EGU General Assembly Conference Abstracts, Vienna, Austria, 23-28 April 2017; Volume 19, p. 13163.

24. Gu, Z. Analyzing bankruptcy in the restaurant industry: A multiple discriminant model. Int. J. Hosp. Manag. 2002, 21, 25-42. [CrossRef]

25. Gu, Z.; Gao, L. A multivariate model for predicting business failures of hospitality firms. Tour. Hosp. Res. 2000, 2, 37-49. [CrossRef]

26. Kim, H.; Gu, Z. Predict US restaurant firm failures: The artificial neural network model versus logistic regression model. Tour. Hosp. Res. 2010, 10, 171-187. [CrossRef]

27. Park, S.S.; Hancer, M. A comparative study of logit and artificial neural networks in predicting bankruptcy in the hospitality industry. Tour. Econ. 2012, 18, 311-338. [CrossRef]

28. Kaniovski, S.; Peneder, M.; Smeral, E. Determinants of firm survival in the Australian accommodation sector. Tour. Econ. 2008, 14, 527-543. [CrossRef] 
29. Williamson, O.E. Hierarchical control and optimum firm size. J. Political Econ. 1967, 75, 123-138. [CrossRef]

30. Scherer, F.M. Changing perspectives on the firm size problem. In Innovation and Technological Change: An International Comparison; Acs, Z.J., Audretsch, D.B., Eds.; Michigan Press: Ann Arbor, MI, USA, 1991.

31. Dhawan, R. Firm size and productivity differential: Theory and evidence from a panel data of US firms. J. Econ. Behav. Organ. 2001, 44, 269-293. Available online: https://pdfs.semanticscholar.org/1ab9/ a91fbcc9e903414dd985589d90415dbea08a.pdf (accessed on 25 July 2018). [CrossRef]

32. Sánchez Pulido, L.; Daries, N.; Cristobal-Fransi, E. Economic sustainability and financial situation of the alpine ski resorts on the Catalan Pyrenees. Intang. Cap. 2016, 12, 1451-1483. [CrossRef]

33. Kaján, E.; Tervo-Kankare, K.; Saarinen, J. Cost of adaptation to climate change in tourism: Methodological challenges and trends for future studies in adaptation. Scand. J. Hosp. Tour. 2015, 15, 311-317. [CrossRef]

34. Steiger, R.; Scott, D.; Abegg, B.; Pons, M.; Aall, C. A critical review of climate change risk for ski tourism. Curr. Issues Tour. 2017, 1-37. [CrossRef]

35. Abegg, B.; Steiger, R.; Trawöger, L. Resilience and perceptions of problems in Alpine regions. In Tourism and Resilience; CABI: Wallinford, UK, 2017; pp. 105-188.

36. Bonzanigo, L.; Giupponi, C.; Balbi, S. Sustainable tourism planning and climate change adaptation in the Alps: A case study of winter tourism in mountain communities in the Dolomites. J. Sustain. Tour. 2016, 24, 637-652. [CrossRef]

37. Uhlmann, B.; Goyette, S.; Beniston, M. Sensitivity analysis of snow patterns in Swiss ski resorts to shifts in temperature, precipitation and humidity under condition of climate change. Int. J. Climatol. 2009, 29, 1048-1055. [CrossRef]

38. Scott, D.; McBoyle, G.; Mills, B. Climate change and the skiing industry in southern Ontario (Canada): Exploring the importance of snowmaking as a technical adaptation. Clim. Res. 2003, 23, 171-181. [CrossRef]

39. Rutty, M.; Scott, D.; Johnson, P.; Jover, E.; Pons, M.; Steiger, R. Behavioural adaptation of skiers to climatic variability and change in Ontario, Canada. J. Outdoor Recreat. Tour. 2005, 11, 13-21. [CrossRef]

40. Dawson, J.; Scott, D.; Havitz, M. Skier demand and behavioural adaptation to climate change in the US Northeast. Leisure/Loisir 2013, 37, 127-143. [CrossRef]

41. Dawson, J.; Scott, D. Systems analysis of climate change vulnerability for the US Northeast ski sector. Tour. Hosp. Plan. Dev. 2010, 7, 219-235. [CrossRef]

42. Moen, J.; Fredman, P. Effects of Climate Change on Alpine Skiing in Sweden. J. Sustain. Tour. 2007, 15, 418-437. [CrossRef]

43. Bicknell, S.; McManus, P. The canary in the coalmine: Australian ski resorts and their response to climate change. Geogr. Res. 2006, 44, 386-400. [CrossRef]

44. Hennessy, K.; Whetton, P.; Smith, I.; Bathols, J.; Hutchinson, M.; Sharples, J. Climate change on snow conditions in mainland Australia and adaptation at ski resorts through snowmaking. Clim. Res. 2008, 35, 255-270. [CrossRef]

45. Fukushima, T.; Kureha, M.; Ozaki, N.; Fujimori, Y.; Harasawa, H. Influences of air temperature change on leisure industries: Case study on ski activities. Mitig. Adapt. Strat. Glob. Chang. 2003, 7, 173-189. [CrossRef]

46. March, H.; Saurí, D.; Llurdés, J.C. Perception of the effects of climate change in winter and summer tourist areas: The Pyrenees and the Catalan and Balearic coasts, Spain. Reg. Environ. Chang. 2014, 14, 1189-1201. [CrossRef]

47. Hendrikx, J.; Hreinsson, E.Ö.; Clark, M.P.; Mullan, A.B. The potential impact of climate change on seasonal snow in New Zealand: Part I-An analysis using 12 GCMs. Theor. Appl. Clim. 2012, 110, 607-618. [CrossRef]

48. Dyllick, T.; Hockerts, K. Beyond the business case for corporate sustainability. Bus. Strategy Environ. 2002, 11, 130-141. [CrossRef]

49. Berger, A.N.; Humphrey, D.B. Efficiency of financial institutions: International survey and directions for future research. Eur. J. Oper. Res. 1997, 98, 175-212. [CrossRef]

50. Ferrier, G.D.; Lovell, C.A.K. Measuring cost efficiency in banking: Econometric and linear programming evidence. J. Econom. 1990, 46, 229-245. [CrossRef]

51. Gallizo, J.L.; Moreno, J.; Salvador, M. European banking integration: Is foreign ownership affecting banking efficiency? J. Bus. Econ. Manag. 2015, 16, 340-368. [CrossRef]

52. Koop, G.; Osiewalski, J.; Steel, M.F.J. Bayesian efficiency analysis through individual effects: Hospital cost frontier. J. Econom. 1997, 76, 77-105. [CrossRef] 
53. Kleit, A.N.; Terrell, D. Measuring potential efficiency gains from deregulation of electricity generation: A bayesian approach. Rev. Econ. Stat. 2001, 83, 523-530. [CrossRef]

54. Anderson, R.I.; Fish, M.; Xia, Y.; Michello, F. Measuring efficiency in the hotel industry: A stochastic frontier approach. Int. J. Hosp. Manag. 1999, 18, 45-57. [CrossRef]

55. Assaf, A.G. Benchmarking the Asia Pacific tourism industry: A Bayesian combination of DEA and stochastic frontier. Tour. Manag. 2012, 33, 1122-1127. [CrossRef]

56. Barros, C.P.; Matias, A. Assessing the efficiency of travel agencies with a stochastic cost frontier: A Portuguese case study. Int. J. Tour. Res. 2006, 8, 367-379. [CrossRef]

57. Assaf, A.; Agbola, F.W. Total productivity in the Australian hotel industry: Estimating and bootstrapping Malmquist indices. Tour. Anal. 2011, 16, 295-304. [CrossRef]

58. Assaf, A.G.; Barros, C.P.; Josiassen, A. Hotel efficiency: A bootstrapped metafrontier approach. Int. J. Hosp. Manag. 2010, 29, 468-475. [CrossRef]

59. Barros, C.P.; Alves, P. Productivity in tourism industry. Int. Adv. Econ. Res. 2004, 10, 215-225. [CrossRef]

60. Barros, C.P.; Mascarenhas, M.J. Technical and allocative efficiency in a chain of small hotels. Int. J. Hosp. Manag. 2005, 24, 415-436. [CrossRef]

61. Carlucci, F.; Cirà, A.; Coccorese, P. Measuring and explaining airport efficiency and sustainability: Evidence from Italy. Sustainability 2018, 10, 400. [CrossRef]

62. Gillen, D.; Lall, A. Non-parametric measures of efficiency of U.S. airports. Int. J. Transp. Econ. 2001, 28, 283-306.

63. Reynolds, D.; Thompson, F.M. Multinunit restaurant productivity assessment using three-phase data envelopment analysis. Int. J. Hosp. Manag. 2007, 26, 20-32. [CrossRef]

64. Roberts, S.; Tribe, J. Sustainability indicators for small tourism enterprises-An exploratory perspective. J. Sustain. Tour. 2008, 16, 575-594. [CrossRef]

65. Gonçalves, O. Efficiency and productivity of French ski resorts. Tour. Manag. 2013, 36, 650-657. [CrossRef]

66. Falk, M. A survival analysis of ski lift companies. Tour. Manag. 2013, 36, 377-390. [CrossRef]

67. Massons, J. La Rendibilitat de les Estacions Catalanes D'esquí Alpí. Ph.D. Thesis, Escuela Superior de Administración y Dirección de Empresas, ESADE, Ramon Llull University, Barcelona, Spain, 2007.

68. Amat, O.; Lloret, P.; Manini, R. Ratios Sectoriales 2016; Colección Manuales, ACCID, Eds.; ACCID: Barcelona, Spain, 2018; p. 312.

69. Groppelli, A.A.; Nikbakht, E. Barron's Finance; Barron's Educational Series: New York, NY, USA, 2000; pp. 1-445, ISBN 978-0764134203.

70. Agrawala, S. Climate Change in the European Alps: Adapting Winter Tourism, and Natural Hazards Management; OECD: Paris, France, 2007. [CrossRef]

71. Steiger, R. The impact of snow scarcity on ski tourism: An analysis of the record warm season 2006/2007 in Tyrol (Austria). Tour. Rev. 2011, 66, 4-13. [CrossRef] 